\title{
AZ INTEGRÁLT VÁLLALATIRÁNYÍTÁSI RENDSZEREK GYAKORLATORIENTÁLT OKTATÁSÁNAK LEHETŐSÉGEI
}

\author{
Zörög Zoltán
}

mérnöktanár, Károly Róbert Föiskola, Gyöngyös

\section{SUMMARY}

In our accelerating world information, information flow and information disclosure are coming to the foreground to a greater extent. The world of business is changing day by day and obtaining information has several pitfalls as we can easily meet information systems that do not provide us with the piece of information expected.

There are high expectations not only for the systems themselves but also for their operators, i.e. the fresh graduates who manage them. In my opinion the practice-oriented education of students is indispensable in this area, as well. While using integrated enterprise resource planning, the systematic way of thinking plays a vital role in addition to the fact that only the data that are to make a wellgrounded managerial decision must be disclosed of the millions of recorded data at the right time.

My paper aims at making the teaching of enterprise resource planning more practice-oriented and tailoring them to labour market expectations.

Keywords: information management, enterprise resource planning, integrated enterprise information systems

\section{BEVEZETÉS}

Az elmúlt évtizedek során az adatok kezelése és a vállalaton belüli kommunikáció jelentősen átalakult. Eleinte csak néhány számítógép került beszerzésre a vállalatoknál, ezért a szervezeti egységek külön-külön építették ki a vállalati adminisztráció területeit lefedö alkalmazásokat, így úgynevezett szigetmegoldások jöttek létre. Mivel ezek nem egymással együttmüködő egységes rendszert képeztek, ezért adatbázisaik szinkronizálása nagyon nehézkesnek bizonyult. Egyazon gazdasági esemény többszöri rögzítéséböl adódó hibák miatt sokszor téves adatokat tartalmazó jelentések kerültek a vezetők asztalára és a használt alkalmazások müködése hosszú távon rendkívül költségesnek volt mondható.

$\mathrm{Az}$ említett szigetszerü megoldások hátrányainak kiküszöbölésére egyre több vállalat vezetése döntött az integrált vállalatirányítási rendszer bevezetése mellett. A rendszerek elterjedésében nagy szerepe volt annak is, hogy egyre több multinacionális vállalat helyezte telephelyét, raktárát, üzemét Magyarországra és hozta magával a külföldön már jól bevált információ technológiai megoldásokat. A bevezetett rendszerek jól áttekinthető, egymással együttmüködő alrendszerekböl álltak, modularitásuk lehetővé tette nem csak a bevezetés fokozatosságát - amely már önmagában sem hátrány, ismerve a rendszerek árát, üzemeltetési költségeit -, hanem e tulajdonság birtokában lehetőség nyílt arra, hogy a teljes vállalati struktúrát lefedjék egyetlen szoftver alkalmazásával.

A téma aktualitását abban látom, hogy az elmúlt évek során - ha nem is rohamosan, de mégiscsak érzékelhető iramban - növekedett azoknak a vállalatoknak a száma, amelyek kihasználják az informatika nyújtotta lehetőségeket, és integrált vállalatirányítási rendszer használata mellett döntöttek. Ennek eredményeként a felsőoktatási intézményeknek figyelembe kell venni e vállalatok elvárásait a vállalatirányítási rendszerek használatához kapcsolódó ismeretek átadására vonatkozóan.

\section{IRODALMI ÁTTEKINTÉS}

Az áttanulmányozott irodalom szerzői egyetértenek abban, hogy az információ hasonlóan a tőkéhez, vagy a munkaerőhöz - napjainkra erőforrássá nötte ki magát. Az információ-menedzsment nem csak a menedzsment információs rendszerek tudománya, nem csak a végfelhasználói szoftverek létrehozásának technikája, nem csak számítástechnika és 
nem csak rendszerszervezés, hanem mindezek együttese. Esetleg valamivel több is ezeknél: szemléletmód, gazdálkodási technika azoknak a közgazdászoknak, rendszerszervezőknek, mérnököknek a számára, akiknek célja az információs erőforrások olcsóbb használata, a vállalati információs vagyon jobb kihasználása (DOBAY, 2003).

KAPRONCZAI (2007) megfogalmazásában az információ célorientált funkcionális tudást jelent, amely a döntések elökészitését és végrehajtását szolgálja.

HÁGEN (2009) kutatásának eredményeként felhivja a figyelmet arra, hogy a vállalkozások hatékony müködésének fenntartásához elengedhetetlen az új eljárások, módszerek adaptációja, nyitottnak kell lenni az új innovatív rendszerek iránt, és ezeket meg kell próbálni beépíteni a döntéshozatal mechanizmusába. Mindehhez nagy segítséget nyújthatnak az integrált vállalatirányítási rendszerek, mint ahogyan ezt HERDON - RÓZSA (2011) is megállapítja. Kihangsúlyozzák, hogy a rendszerek keretet nyújtanak az információk gyűjtéséhez, feldolgozásához és továbbításához, kiszolgálva a termelési, szolgáltatási, irányítási feladatokat.

\section{ANYAG ÉS MÓDSZER}

Kutatási tevékenységem során két kérdōíves megkeresést végeztem. Az első esetében a vállalati információs rendszerek müködtetését, a diplomásokkal szembeni elvárásokat feltáró felmérésre helyeztem a hangsúlyt. A kérdöíveket az integrált vállalati információs rendszert használó vállalkozásokhoz juttattam el. A kialakult mintába 181 vállalkozás által kitöltött kérdöív adatai kerültek. A második felmérés segítségével elsősorban arra kerestem a választ, hogy a gazdálkodási, és mezőgazdasági szakokkal rendelkező felsőoktatási intézmények, vállalati információs rendszerekkel kapcsolatos oktatási tevékenysége milyen mértékben felel meg a munkáltatók elvárásainak? A kérdőíveket 26 intézménybe juttattam el, azoknak az intézményvezetőknek, tanszékvezetőknek, akiknek a gondozásába vállalati információs rendszerekhez kapcsolódó tantárgyak tartoznak.

\section{VIZSGÁLATI EREDMÉNYEK ÉS AZOK ÉRTÉKELÉSE}

Magyarországon folyamatosan növekszik azoknak a vállalatoknak a száma, amelyek egy integrált rendszer segítségével kísérlik meg piaci poziciójukat megtartani, vagy azt megerősíteni ${ }^{1}$. Ennek megfelelően a felsőoktatásból a munkaerőpiacra kerülő pályakezdők egyre nagyobb eséllyel nyújtják be jelentkezésüket olyan vállalathoz, ahol szükség lehet azokra az ismeretekre, amelyet a felsöoktatásban eltöltött évek alatt megszereztek az információ menedzsment területén. Az 1. ábra szemlélteti a vállalatirányítási rendszereket használó cégek számát, amely 2008 és 2010 között folyamatosan növekvő tendenciájú.

$\mathrm{Az}$ ábra tanúsága szerint ez aránynövekedést is jelent, hiszen a vállalatok száma ezzel szemben csökkenő tendenciát mutat. $\mathrm{Az}$ integrált rendszert használó vállalatok számának növekedése ugyan nem robbanásszerü, viszont az ERP rendszert 2010-ben bevezető vállalatok száma majdnem kétszerese a 2009-es évbeli értéknek. Mindenképpen figyelembe kell venni, hogy összességében 2010-ben 8\% volt Magyarországon az ERP rendszert használó vállalatok aránya.

\footnotetext{
${ }^{1}$ MICHELBERG (2004) alapján hazánkban az árbevétel szerinti elsõ 200 vállalatnak volt integrált vállalatirányútási rendszere.
} 


\section{1. ábra: Az integrált vállalatirányítási rendszert használó vállalatok száma Magyarországon}

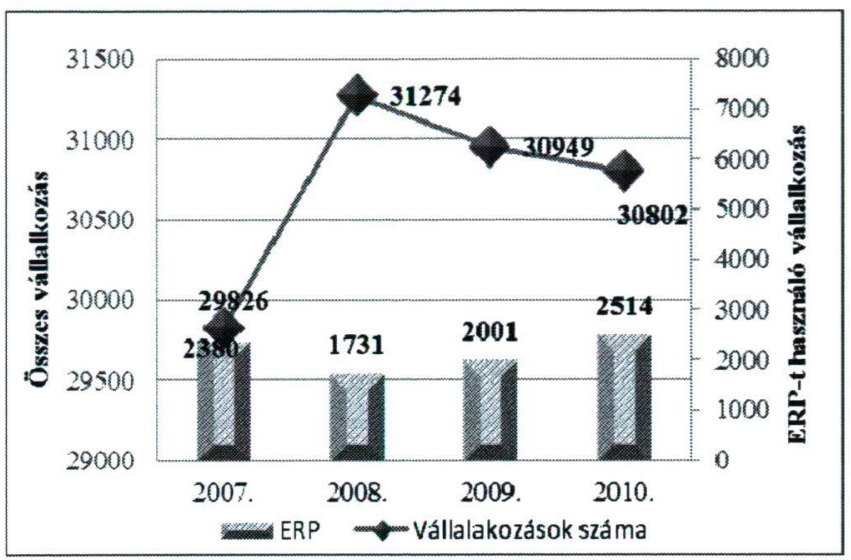

Forrás: KSH adatok alapján saját szerkesztés

Ha a 2. ábrán bemutatott adatok alapján a vállalati méretkategória szerint vizsgáljuk a vállalatirányítási rendszert használó vállalatok megoszlását, azonos irányú változás figyelhetö meg, mint az 1. ábrán.

2. ábra: Az ERP-t használó vállalatok száma az összes vállalat százalékában Magyarországon

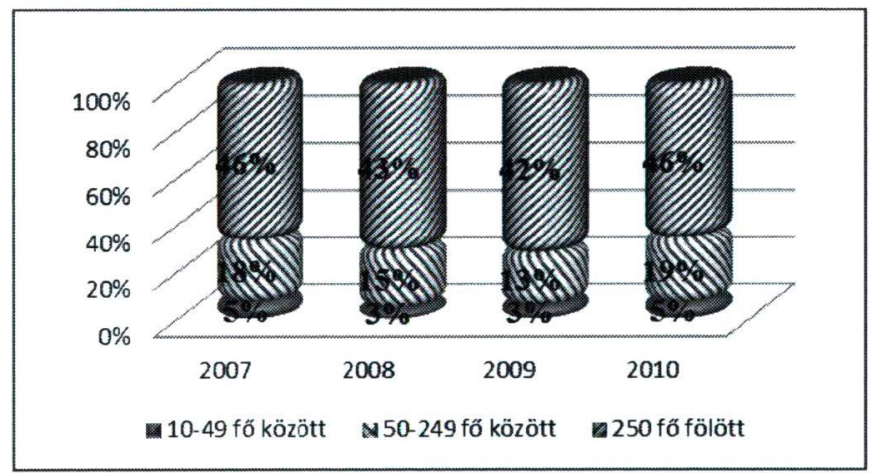

Forrás: KSH adatok alapján saját szerkesztés

Látható, hogy 2010-ben a magyarországi nagyvállalatok (883 vállalat) közel fele (404 vállalat) helyez nagy hangsúlyt a vállalaton belüli gyors, folyamatos, pontos információáramlásra. A közepes méretű vállalatok esetében a 2010-es megoszlás meghaladja a 2007-es értéket, az előző évihez viszonyítva pedig jelentős növekedés tapasztalható.

Ezen kívül megállapítást nyert, hogy az integrált vállalatirányítási rendszert használó vállalkozások fele négy nemzetgazdasági ágazatban tevékenykedik: pénzügy, kereskedelem, feldolgozóipar, energiaipar. Ráadásul az Educatio Társadalmi Szolgáltató Nonprofit Kft. által elvégzett országos diplomás pályakövető felmérés adatai alapján a felsőoktatási intézményekből kikerülő gazdálkodási és mezőgazdasági szakon végzett hallgatók harmada helyezkedik el a fenti tevékenységet folytató vállalkozás valamelyikénél.

A primer kutatás során - kérdőíves felmérés keretében - megkeresett integrált vállalatirányítási rendszert használó vállalatok képviselői a következőképpen nyilatkoztak a 
diplomás pályakezdőkkel szemben támasztott elvárásaikról. A vállalati információs rendszer használatával összefüggő elvárások erősségét 1-5 fokozatú skálán értékelhették a válaszadók (3. ábra).

\section{3. ábra: A vállalat elvárása a vállalati információs rendszer használatára vonatkozóan}

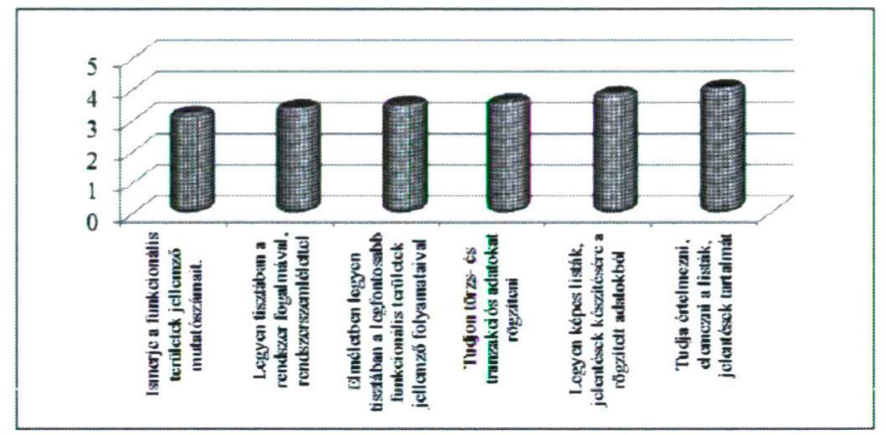

Forrás: saját szerkesztés

Az ábra adatai 3,2-4,1 között változnak. A kapott átlagértékek azt mutatják, hogy az igények meglehetősen egyöntetüek az információs rendszer használatára vonatkozóan. Kisebb mértékben várják el azt, hogy a diplomás pályakezdő legyen képes egy számára ismeretlen rendszerben a gazdasági eseményekhez kapcsolódó adatok rögzítésére. Azt viszont inkább fontosnak tartják, hogy az előállított kimutatások, listák, jelentések tartalmát tudja értelmezni, elemezni, illetve el tudja ezeket készíteni.

A fenti adatok alapján vizsgáltam az elvárások, és munkahelyi tapasztalat közti összefüggést. Az 1. táblázat adatai alapján $5 \%$ hibahatár mellett mutatható ki a szignifikancia

\section{1. táblázat: A pályakezdőkkel szembeni elvárások a munkahelyi tapasztalat függvényében}

\begin{tabular}{|l|c|c|c|}
\multicolumn{2}{c}{ munkahelyi tapasztalat fuggvényében } & \multicolumn{2}{c|}{ Test Statistics a,b } \\
\cline { 2 - 4 } \multicolumn{1}{l|}{} & $\begin{array}{c}\text { Chi- } \\
\text { Square }\end{array}$ & df & $\begin{array}{c}\text { Asymp. } \\
\text { Sig. }\end{array}$ \\
\hline $\begin{array}{l}\text { Legyen tisztában a rendszer fogalmával, a rendszerszeml- } \\
\text { élettel }\end{array}$ & 6,11 & 3 & 0,106 \\
\hline $\begin{array}{l}\text { Elméletben legyen tisztában a legfontosabb funkcionális } \\
\text { területek jellemző folyamataival. }\end{array}$ & 2,21 & 3 & 0,529 \\
\hline Ismerje a funkcionális területek jellemző mutatószámait & 4,61 & 3 & 0,203 \\
\hline Tudjon törzsadatokat, tranzakciós adatokat rögzíteni & 3,65 & 3 & 0,302 \\
\hline $\begin{array}{l}\text { Legyen képes listák, jelentések készítésére a rögzített } \\
\text { adatokból }\end{array}$ & $\mathbf{1 5 , 4 5}$ & $\mathbf{3}$ & $\mathbf{0 , 0 0 1}$ \\
\hline Tudja értelmezni, elemezni a listák jelentések tartalmát & 4,36 & 3 & 0,225 \\
\hline
\end{tabular}

a.

b.
Kruskal Wallis Test

Grouping Variable: Hány éve dolgozik a vállalatnál?

Forrás: saját szerkesztés

A Kruskal-Wallis teszt eredménye alapján elsősorban azok a válaszadók támasztják követelményként a pályakezdőkkel szemben a listák, jelentések készítésének képességét, akik 9-15 év dolgoznak az adott vállalatnál. 
Az elvárások meghatározása után fontos tényező, hogy a felsőoktatási intézmények milyen mértékben teljesítik ezt az elvárást, egyáltalán fektetnek-e hangsúlyt a vállalatirányítási rendszerek használatának oktatására. A felmérés eredményeként a logisztika, marketing, műszaki menedzser, vállalkozásfejlesztés szakokon, a szakkal rendelkező valamennyi intézmény tantervében szerepelnek a vállalatirányítási rendszerekhez kapcsolódó tantárgyak. Véleményem szerint sajnálatosnak mondható, hogy a kereskedelmi és marketing szakkal rendelkező 14 intézményből mindössze 5-ben, vezetés és szervezés szakkal rendelkező 9 intézményből pedig csupán 1-ben fektetnek hangsúlyt integrált információs rendszer oktatására. Az első eredmény azért mondható aggasztónak, mert a kereskedelmi tevékenységet folytató vállalatok meglehetősen gyakran üzemeltetnek ilyen rendszert. A második pedig azért, mert az említett rendszerek a vezetői döntések meghozatalát segítik elő a vállalkozás müködésére vonatkozó real time adatok biztosításával.

Következő lépésként ötfokozatú skálán került értékelésre az, hogy miért okoz problémát a vállalatirányítási információs rendszerek gyakorlatorientált oktatása (4. ábra).

\section{4. ábra: Vállalati információs rendszerek gyakorlatorientált oktatási nehézségeinek oka}

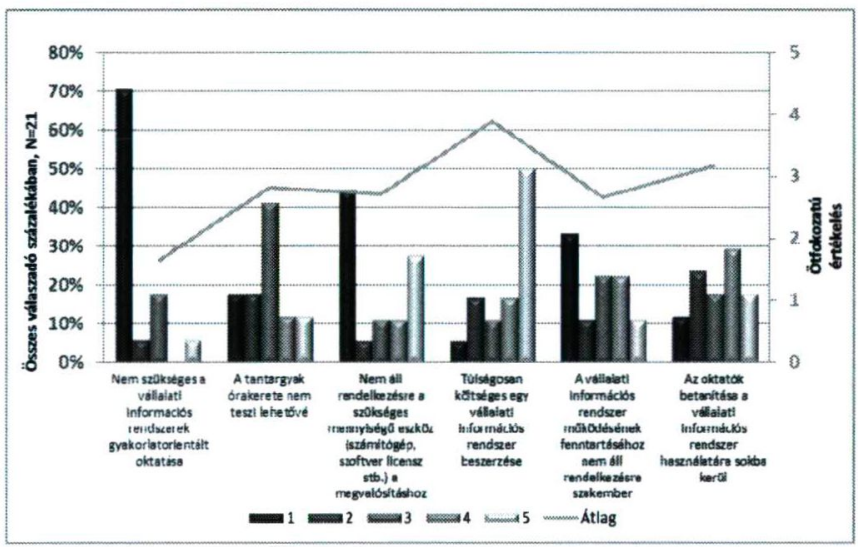

Forrás: saját szerkesztés

Azzal az állítással, hogy nem szükséges az integrált információs rendszerek gyakorlatorientált oktatása jórészt nem értettek egyet a válaszadók. A közepes fontosságot három kitöltő jelezte, egy pedig nem tartja szükségesnek. A 4. ábráról leolvasható, hogy a legnagyobb számú 5-ös értékelést a magas beszerzési költség kapta, ennek megfelelően az átlagot tekintve is ez lehet az akadálya gyakorlatorientált képzés tényleges megvalósulásának. A közelmúlt pályázati lehetőségeinek köszönhetően az oktatáshoz megfelelő mennyiségü eszköz az intézmények többségénél rendelkezésre áll. 5 esetben nyilatkoztak problémáról ezzel a tényezővel összefüggésben. Szinte ugyanez mondható el az üzemeltetés fenntartásához szükséges szakember (rendszergazda) állománnyal kapcsolatban is.

Miután a 4. ábra alapján a válaszadók majdnem fele nyilatkozik az órakeret szükösségéröl, felvetődik a kérdés, hogy egyéb, az információmenedzsmenthez közvetlenül nem kapcsolódó tárgy esetében oktatják-e a rendszerek használatát. A válaszadó intézményekben a vállalatgazdaságtan, ellenőrzés, marketing, ügyviteli ismeretek, projektmenedzsment, kvantitatív módszerek, e-business tárgyak oktatásába „,csempészik be” a vállalati információs rendszer használatát. Az 5. ábra mutatja, hogy egyéb tárgyak oktatásába való bevezetés miért jelent nehézséget? 


\section{5. ábra: A vállalati információs rendszerekhez közvetlenül nem köthető tantárgyak gyakorlatorientált oktatásának nehézségei}

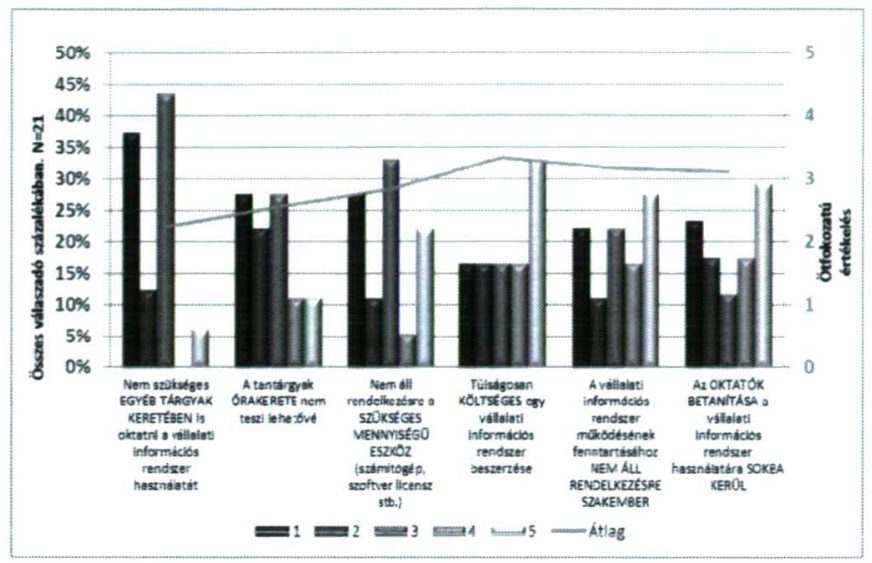

Forrás: saját szerkesztés

A kérdésekre adott válaszok ötfokozatú skálán adott értékelések átlaga alapján megállapítom, hogy valamennyi felvázolt probléma hozzávetölegesen közepes mértékben egyöntetüen okozza, hogy a vállalati információs rendszerek oktatása nem kerül be egyéb tárgyak oktatási tematikájába. Arra vonatkozóan, hogy van-e erre szükség, a válaszadók harmada nyilatkozik úgy, hogy minimális mértékben ért egyet a szükségtelenséggel, a másik harmad közepes mértékben ért egyet. Mindössze egy válaszadó tartja szükségtelennek a felvetésemet. A szöveges indoklások alapján a kitöltők szintén az egyéb tárgyakba integrálás mellett nyilatkoznak. A következő előnyök kerülnek megfogalmazásra:

- a rendszerszemléletủ gondolkodásmód fejlesztésének a lehetősége,

- a közvetlen tapasztalatszerzés,

- az alkalmazási lehetőségek bemutatásával a leendő munkahelyen való akklimatizálódás,

- az adott tantárgy érdekesebbé válása.

Ezeken kívül fontos lehet, hogy mivel a legkülönfélébb gazdasági területen közigazgatás, szolgáltatás, HR, logisztika stb. - használnak vállalati információs rendszert, ezekhez kapcsolódó tantárgyak keretében egyre inkább fontos tényező az illető területen jellemző gazdasági folyamatokat lefedő rendszer működésének oktatása.

A munkaerő-piaci szereplök a vállalati információs rendszerek oktatásával kapcsolatban elsősorban azt várják el, hogy a diplomás pályakezdők legyenek képesek a döntéshozatalhoz szükséges tartalommal rendelkező listák, jelentések előállítására, esetleg elemzésére. Ha ezeket egy vállalati információs rendszeren belül követni is tudják, elönyösebb helyzetbe kerülnek a munkaerőpiacon. Véleményem szerint ehhez szükséges nemcsak a klasszikusnak mondható tantárgyak keretében oktatni a vállalati információs rendszerek használatát a gazdálkodási és mezőgazdasági szakokon. 


\section{KÖVETKEZTETÉSEK}

Összegzésként megállapítom, hogy a vállalati információs rendszerek gyakorlatorientált oktatása a felsőoktatási intézmények többségének számára fontos szempont. A megvalósítással kapcsolatban a rendszerek beszerzésének költségeit emelték ki korlátozó tényezöként.

A munkaeröpiaci elvárásoknak a lista, és jelentés készitésére vonatkozóan válaszadó intézmények mintegy harmada ( 7 intézmény) felel meg. Az elkészített kimutatások elemzését az intérmények ötöde tartja fontosnak. Ahhoz, hogy a hallgatók ismeretszintje megfeleljen az igényeknek - figyelembe véve, hogy a kérdöiv kitöltöinek $40 \%$-a értékelte közepes problémának a szükös órakeretet - egyéb lehetőséget kell megragadni az ismeretek bővitésére. Lehetőséget látok a vállalati információs rendszerek oktatásának bevonására egyéb, nem közvetlenül kapcsolódó tárgyak keretében. Ezt teljes mértékben elvetendö lehetöségként (5-ös osztályzattal) a válaszadók mintegy 5\%-a jelölte meg. Teljes mértékben egyetértöen a kitöltök harmada, közepes mértékben pedig közel fele nyilatkozott.

A gyakorlatorientált képzés megvalósulásához egyik javaslatom, hogy a tudományterülethez szorosan kapesolódó tantárgyak gyakorlati óráin egy adott vállalati információs rendszer müködését, használatát ismerjék meg a hallgatók. Ezen kivül az információ menedzsmenthez szorosan nem kapcsolódó tárgyak esetében bemutató jelleggel egy-egy gyakorlaton, egy adott témakör tárgyaláskor a vállalatirányítási információs rendszert hívják segítségül egy marketing-, vállalatgazdaságtani-, logisztikai-, vagy pénzügyi probléma megoldásakor. Eredményül a hallgatók nem csak a legkülönfélébb területekhez kapcsolódóan tapasztalják meg a vállalati információs rendszer müködtetésének a hasznát, hanem a feladatok megoldásával gyakorlatot is szereznek a rendszer müködtetésében, és nem utolsó sorban az informatikai készségeik is fejlödnek.

\section{FELHASZNÁLT IRODALOM}

Dobay P. (2003): Vállalati információmnedzsment, Nemzeti tankönyvkiadó, Budapest Kapronczai I. (2007): Információs rendszerek a közös agrárpolitika szolgálatában, Szaktudás Kiadó Ház, Budapest

Hágen, I. Zs. - Kondorosi F- né (2009): Üzleti tervezés, Controll 2003 KFT., Debrecen

Herdon M. - Rózsa T. (2011): Információs rendszerek az agrárgazdaságban, Szaktudás Kiadó Hảz Rt., Budapest 